Vol. 24, No. 3, Juli 2021, hlm. 486-495

p-ISSN: 1410-9344; e-ISSN: 2549-5631

WARTA LPM

homepage: http://journals.ums.ac.id/index.php/warta

\title{
Pembuatan Sistem Less Hand Touch sebagai Upaya Mengurangi Penyebaran Covid-19
}

\author{
Riska Ekawita, Supiyati, Elfi Yuliza \\ Program Studi Fisika FMIPA, Universitas Bengkulu \\ Email: rekawita@unib.ac.id
}

\section{Article Info}

Submitted: 26 January 2021

Revised: 19 May 2021

Accepted: 21 June 2021

Published: 20 July 2021

Keywords: Covid-19, less hand touch, public facilities, hand washing system
Kata kunci: Covid-19, mencuci tangan, fasilitas umum, less hand touch system

\section{Abstract}

The use of soap and water or hand sanitizer that contains at least 60\% alcohol can slay viruses and germs. Therefore, routine hand washing is one of the health protocols that is implemented especially during the Covid-19 pandemic with the aim of reducing the spread of the corona virus. However, the hand washing systems available, especially in public facilities, are still limited and manually in operation. Therefore, the objective of this service is to provide hand washing equipment with less hand touch system which is placed in public facilities. It is hoped that this activity can help the community in reducing the spread of the virus. This paper describes the mechanism for making a hand washing system and submitting the system to several public facilities. The less hand touch system consists of an automatic hand wash, an automatic hand sanitizer and a pedal system-based hand wash. An automatic system is made by utilizing ultrasonic sensors and Arduino as controllers. Meanwhile, a pedal system uses the user's feet as a control for the hand washing process. The building of the system is divided into 2 stages, namely the construction of the hardware and software part. Then, the system was placed in public facilities as an effort to prevent the spread of Covid-19. The delivery of the ready-to-use less hand-touch hand washing system to the participants involved several participants i.e. village officials, community health center staff and the mosque elements. Then, the training on the use and maintenance of the system was also carried out which was given to the person in charge appointed by the participant for each element. Furthermore, the provision of this equipment can support the efforts made by public facility managers in carrying out government recommendations, especially during the Covid-19 pandemic.

Abstrak
Penggunaan sabun dan air ataupun cairan pembersih tangan yang
mengandung minimal $60 \%$ alkohol mampu membunuh virus dan
kuman. Oleh karena itu, rutin mencuci tangan menjadi salah satu
protokol kesehatan yang diterapkan terutama pada masa pandemi


Covid-19 dengan tujuan mengurangi penyebaran virus corona. Namun, sistem pencuci tangan yang tersedia terutama di fasilitas umum masih sangat terbatas dan membutuhkan kontak tangan agar sistem beroperasi. Oleh karena itu, pengabdian ini bertujuan untuk menyediakan peralatan pencuci tangan less hand touch yang ditempatkan pada fasilitas umum seperti kantor lurah, puskesmas, dan masjid. Diharapkan dengan kegiatan ini dapat membantu masyarakat sekitar dalam mengurangi penyebaran virus corona. Pada tulisan ini diterangkan mekanisme pembuatan peralatan cuci tangan less hand touch dan penyerahan sistem untuk digunakan di beberapa fasilitas umum. Peralatan less hand touch yang dibuat terdiri dari pencuci tangan otomatis, hand sanitizer otomatis dan pencuci tangan berbasis sistem pedal. Sistem pencuci tangan otomatis dibuat dengan memanfaatkan sensor ultrasonik dan arduino sebagai pengendali sistem. Sedangkan pencuci tangan berbasis pedal dengan memanfaatkan kaki pengguna sebagai kontrol pada proses mencuci tangan. Pembuatan peralatan ini dibagi menjadi 2 tahap, yaitu pembuatan bagian hardware dan bagian software. Peralatan yang telah dibuat selanjutnya ditempatkan pada fasilitas umum sebagai upaya pencegahan penyebaran Covid-19. Penyerahan sistem pencuci tangan less hand touch siap pakai pada partisipan melibatkan beberapa partisipan dari berupa unsur kelurahan, unsur pengelola puskesmas, dan pengurus masjid. Kemudian juga dilakukan pelatihan penggunaan dan perawatan sistem yang diberikan kepada penanggung jawab yang ditunjuk oleh partisipan pada setiap unsur. Lebih lanjut, penyerahan peralatan ini dapat mendukung upaya yang dilakukan oleh pengelola fasilitas umum dalam menjalankan himbauan pemerintah terutama selama pandemi Covid-19.

\section{PENDAHULUAN}

Pandemi Covid-19 yang mulai merebak pada akhir 2019 di China telah mengubah pola pandangan masyarakat di seluruh dunia terutama terhadap kesehatan dan interaksi sosial (Mondada et al., 2020; Ogden, 2020). Mekanisme dan kecepatan penyebaran serta gejala dan dampak yang ditimbulkan menyebabkan tingkat kewaspadaan tinggi terhadap penyebaran wabah ini. Otoritas kesehatan dunia, WHO telah memaparkan berbagai upaya yang dapat dilakukan selama masa pandemi Covid-19 (WHO, 2020). Upaya pencegahan penyebaran Covid-19 dapat dilakukan dengan menerapkan protokol kesehatan (prokes) yang terdiri dari penggunaan masker, rajin mencuci tangan, menjaga jarak, dan menghindari kerumunan (5M) (Saputra et al., 2021; Lestari et al., 2021; Subiyanto \& Widyastuti, 2021). Adanya prokes $5 \mathrm{M}$ ini bersesuaian dengan karakteristik penyebaran virus Corona yakni melalui droplet penderita yang keluar ketika penderita bersin, batuk, ataupun berkomunikasi (Chen, 2020; Zhang et al., 2020; Przekwas \& Chen, 2020). Oleh karena itu, menjaga kebersihan terutama dengan rajin mencuci tangan dapat menjadi upaya dalam menekan laju penyebaran virus corona (Przekwas \& Chen, 2020).

Secara umum, mencuci tangan dapat memperlambat dan bahkan mencegah penyebaran berbagai kuman penyakit termasuk virus Corona. Hasil penelitian baru-baru ini juga menunjukkan bahwa kebiasaan mencuci tangan dapat mengurangi penyebaran Covid-19 hingga 37\% (Nicolaides, dkk. 2019). Oleh karena itu, berbagai cara terus dilakukan pemerintah untuk menggalakkan budaya rajin mencuci tangan seperti memberikan edukasi kepada seluruh masyarakat termasuk instansi layanan umum untuk lebih disiplin dalam hal cuci tangan 
pakai sabun (CTPS) (Rosita, 2020; Meisyaroh et al., 2021; Tucker et al., 2020). Di samping itu, ketersediaan fasilitas mencuci tangan juga perlu ditingkatkan dalam mendukung terlaksananya protokol kesehatan yang lebih disiplin.

Secara umum, ketersediaan fasilitas pencuci tangan di berbagai fasilitas umum masih sangat terbatas. Adapun fasilitas umum yang menyediakan fasilitas pencuci tangan masih menggunakan cara manual yakni membutuhkan kontak tangan agar sistem tersebut bekerja. Sedangkan virus Corona memiliki kemampuan untuk bertahan hidup (beberapa jam) di luar inangnya (Yanti et al., 2020). Oleh karena itu, penyediaan fasilitas pencuci tangan tanpa sentuh sangat dibutuhkan terutama pada berbagai layanan umum untuk menghindari kontak langsung agar dapat mengurangi penyebaran virus Corona. Agar tersedianya fasilitas pencuci tangan yang memadai dan memenuhi kebutuhan terutama di masa pandemi Covid-19, peran aktif berbagai pihak sangat dibutuhkan. Dalam mendukung upaya pemerintah tersebut, dilakukanlah kegiatan pengabdian masyarakat melalui penyediaan peralatan pencuci tangan less hand touch. Sistem less hand touch ini terdiri dari pencuci tangan dan hand sanitizer otomatis yang diserahkan pada penyedia layanan umum seperti masjid, kantor lurah, dan puskesmas.

\section{SENSOR ULTRASONIK DAN MIKROKONTROLER}

Sensor ultrasonik adalah sensor yang bekerja dengan memancarkan sinyal gelombang ultrasonik menuju suatu objek. Sinyal yang dipancarkan akan merambat sebagai gelombang bunyi dengan kecepatan sekitar $340 \mathrm{~m} / \mathrm{s}$.
Objek akan memantulkan kembali gelombang tersebut dan diterima oleh receiver pada sensor. Selanjutnya sensor akan membaca lama waktu pengiriman dan penerimaan kembali gelombang pantul tersebut. Berdasarkan waktu penjalaran gelombang, maka diperoleh jarak objek terhadap sensor ultrasonik dengan menggunakan persamaan 1.

$$
s=\frac{v}{\left(\frac{t}{2}\right)} .
$$

$\mathrm{s}=$ jarak sensor dengan objek $(\mathrm{m})$

$\mathrm{v}=$ kecepatan gelombang ultrasonik $(\mathrm{m} / \mathrm{s})$

$\mathrm{t}=$ waktu penjalaran gelombang $(\mathrm{s})$

Gambar 1 menunjukkan prinsip kerja dari sensor ultrasonik. Ketika gelombang ultrasonik yang dipancarkan oleh transmitter mengenai objek yang berada di depannya, maka gelombang tersebut akan dipantulkan kembali dan diterima oleh receiver. Jarak antara objek dengan sensor dihitung berdasarkan waktu yang ditempuh mulai dari gelombang ditransmisikan hingga diterima kembali oleh receiver. Besarnya jarak yang diizinkan antara sensor dengan objek dapat diatur agar sensor memberikan respon seperti bunyi dan lain sebagainya. Pada sistem pencuci tangan less hand touch, pengaturan jarak yang diizinkan digunakan untuk memberikan respon berupa keluarnya air ataupun sabun. Untuk membaca dan mengolah hasil respon dari sensor ultrasonik ini digunakan sistem mikrokontroler. Secara umum, sistem mikrokontroler telah banyak dan popular digunakan dalam berbagai bidang ilmu seperti bidang kontrol, otomatisasi, pengukuran, dan lain sebagainya (Suhardi,

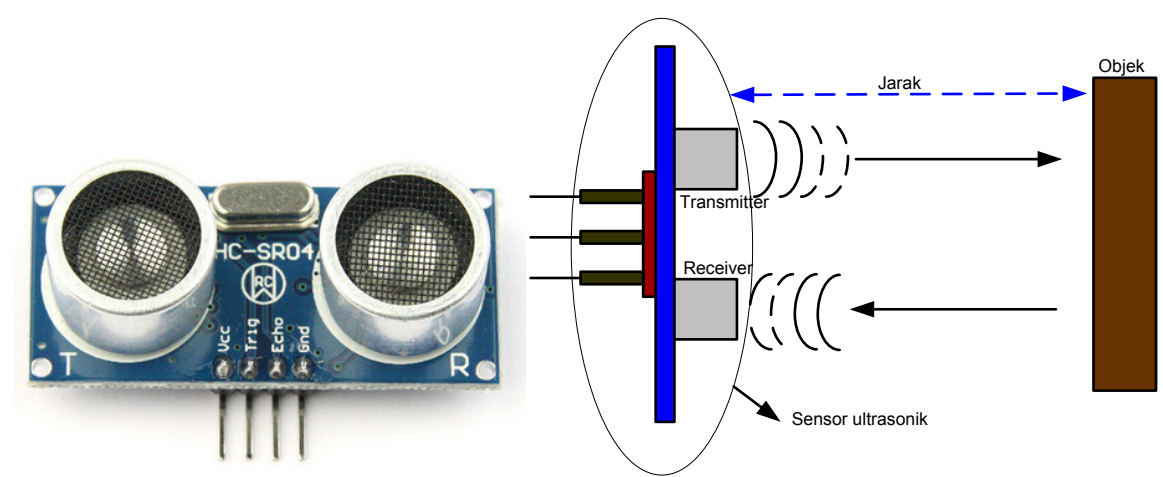

Gambar 1. Sensor Ultrasonik dan Prinsip Kerja 


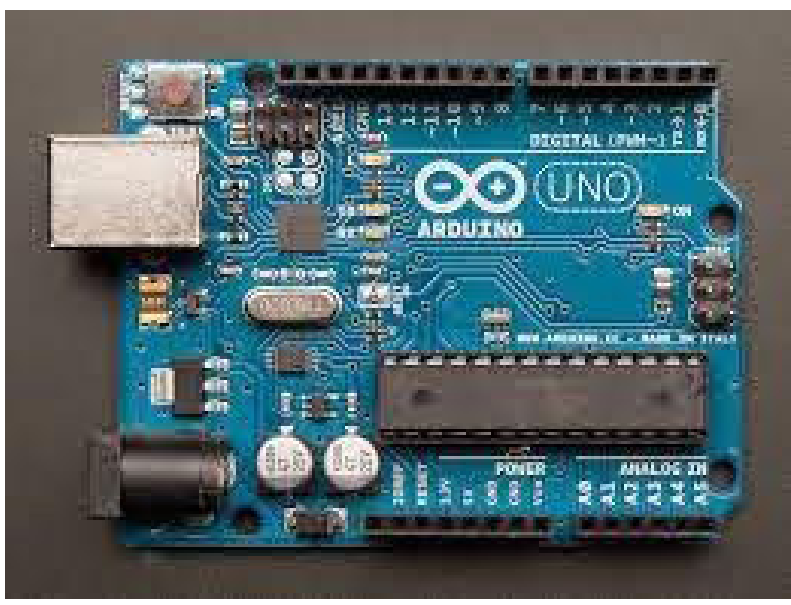

Gambar 2. Mikrokontroler Arduino Uno

2019; Shaputra et al., 2019). Pada sistem ini mikrokontroler yang digunakan adalah tipe Atmega 328 yang terdapat pada board Arduino Uno. Mikrokontroler ini memiliki 14 pin input dari output digital di mana 6 pin input tersebut dapat digunakan sebagai output PWM dan 6 pin input analog, $16 \mathrm{MHz}$ osilator kristal, koneksi USB, jack power, ICSP header, dan tombol reset seperti ditunjukkan pada Gambar 2.

\section{METODE}

Secara umum, kegiatan pengabdian ini bertujuan untuk menyediakan peralatan pencuci tangan less hand touch di beberapa fasilitas umum yang ada di sekitar Universitas Bengkulu sehingga dapat tersebut. Partisipan yang terlibat dalam pelaksanaan kegiatan adalah beberapa unsur pengelola fasilitas umum yakni pertama pengelola kantor kelurahan, kepala kelurahan. dan salah satu karyawan kelurahan menjadi mitra langsung pada saat kegiatan ini. Kedua adalah pengelola masjid, di mana sekretaris takmir dan penjaga masjid menjadi partisipan dari kegiatan pengabdian yang dilakukan. Partisipan yang ketiga adalah kepala puskesmas, salah satu karyawan puskesmas dan penjaga keamanan puskesmas yang terlibat pada kegiatan pengabdian ini. Untuk mencapai tujuan pengabdian, terdapat tiga tahapan utama pelaksanaan kegiatan pengabdian seperti pada Gambar 3. Tahapan pertama diawali dengan desain dan persiapan bahan untuk membuat sistem pencuci tangan less hand touch, kemudian dilanjutkan dengan pembuatan sistem mekanik dan elektronik dari sistem pencuci tangan

\section{Persiapan bahan dan desain}

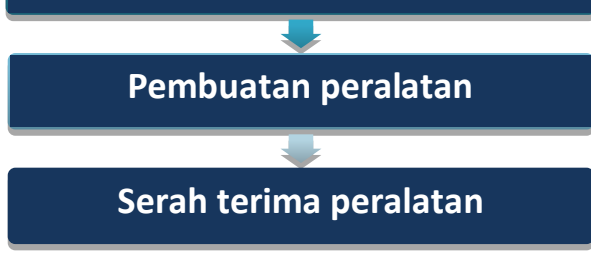

Gambar 3. Tahapan Kegiatan Pengabdian

dan tahapan terakhir penyerahan peralatan tersebut pada penyedia layanan umum seperti tempat ibadah, kantor kelurahan, dan puskesmas. Pengabdian ini merupakan topik khusus dengan tema Covid-19, dan tidak dilakukan melalui pemberian pelatihan agar dapat menghindari terjadinya kerumunan. Oleh karena itu, pembuatan peralatan dilakukan sepenuhnya oleh tim pengabdian dan pembantu pengabdian. Peralatan yang telah dibuat kemudian diserahkan kepada penerima seperti kantor lurah, puskesmas dan masjid. Pada setiap penerima ditunjuk satu orang penanggungjawab yang kemudian diberikan petunjuk teknis penggunaan peralatan, apa yang harus dilakukan jika peralatan tidak bekerja dan nomor kontak pelaksana pengabdian yang dapat dihubungi. Pemberian nomor kontak ini bertujuan untuk tetap memantau performa alat yang telah diserahkan pada penerima.

Bahan yang digunakan pada proses pembuatan sistem less hand touch adalah wastafel, kran air, pipa, sensor ultrasonik, mikrokontroler, lampu LED, buzzer, kabel, sabun cair, sanitizer, dan beberapa besi sebagai tiang penyangga serta botol sebagai wadah cairan pembersih. Sedangkan peralatan yang digunakan untuk pembuatan sistem less hand touch adalah solder, gergaji, tang, obeng, dan lain-lain.

Pada kegiatan pengabdian ini, sistem less hand touch yang dibuat terdiri dari 3 jenis, yaitu sistem pencuci tangan otomatis, sistem hand sanitizer otomatis, dan sistem pencuci tangan berbasis pedal. Secara umum, sistem pencuci tangan otomatis dan sistem hand sanitizer otomatis dikembangkan menggunakan sistem instrumentasi utama yang sama yakni sensor ultrasonik dan mikrokontroler. Sensor ultrasonik digunakan untuk mendeteksi keberadaan objek (tangan) di depan sistem dan mikrokontroler sebagai pengendali kerja. Perbedaan mendasar 
dari kerja kedua sistem ini adalah tahapan kerja yang harus dilakukan oleh sistem. Sistem pencuci tangan memerlukan tahapan kerja yang lebih banyak dibandingkan sistem hand sanitizer. Hal ini juga berkaitan dengan bahan utama yang digunakan. Pada pencuci tangan, perintah yang harus dilakukan sistem adalah mengeluarkan cairan berupa air dan sabun, sedangkan pada sistem hand sanitizer hanya cairan sanitizer. Untuk jenis sistem pencuci tangan less hand touch terakhir adalah sistem pencuci tangan berbasis pedal. Sistem ini dikembangkan dengan memanfaatkan prinsip kerja pedal untuk mengontrol keluarnya air dan sabun dalam proses mencuci tangan menggunakan kaki pengguna.

Tahapan akhir yang dilakukan pada kegiatan pengabdian masyarakat ini adalah serah terima sistem pencuci tangan pada berbagai fasilitas umum. Penentuan fasilitas umum yang terpilih dilakukan berdasarkan beberapa kriteria seperti posisi dan volume aktivitas pada fasilitas umum tersebut. Lebih lanjut, sebelum dilakukan serah terima, terlebih dahulu telah dilakukan komunikasi dengan penanggungjawab fasilitas umum tersebut. Kegiatan serah terima peralatan dilakukan pada waktu yang telah disepakati antara tim pengabdian dengan unsur pengelola pada fasilitas umum terpilih dan dihadiri oleh tim pengabdi dan unsur pengelola dimasing-masing lokasi penempatan peralatan pencuci tangan. Pada kantor kelurahan, kegiatan ini diikuti oleh kepala kelurahan dan salah satu karyawan kelurahan, pada masjid dihadiri oleh sekretaris takmir masjid dan penjaga masjid, serta di puskesmas diikuti oleh kepala puskesmas, salah satu karyawan puskesmas dan penjaga keamanan puskesmas. Pada saat penyerahan ini diberikan contoh cara penggunaan sistem cuci tangan yang diserahkan, bagaimana mengisi ulang komponen yang dibutuhkan seperti sabun dan cairan pembersih lainnya, serta perawatan yang dapat dilakukan. Tanya jawab dan diskusi lisan terjadi dengan penerima peralatan selama melakukan pemaparan tentang pengoperasian alat cuci tangan. Lebih lanjut, pada setiap penerima ditunjuk satu orang penanggung jawab yang kemudian diberikan petunjuk teknis penggunaan peralatan, apa yang harus dilakukan jika peralatan tidak bekerja dan nomor kontak tim pengabdian yang dapat dihubungi. Pemberian nomor kontak ini bertujuan untuk tetap memantau kondisi alat yang telah diserahkan pada penerima.

\section{HASIL DAN PEMBAHASAN}

Perancangan sistem less hand touch merupakan tahapan pertama yang dilakukan pada kegiatan pengabdian ini serta menentukan material dan komponen yang dibutuhkan dalam pembuatan sistem. Pembuatan sistem pencuci tangan membutuhkan berbagai komponen seperti komponen mekanik, elektronik, dan cairan (sabun dan sanitizer). Komponen mekanik yang dibutuhkan diantaranya besi, wastafel, pipa dan akrilik yang digunakan untuk membuat dudukan pencuci tangan dan box sistem kontrolnya. Adapun komponen elektronik yang digunakan berupa sensor, mikrokontroller, buzzer, kabel, serta komponen elektronik lainnya.

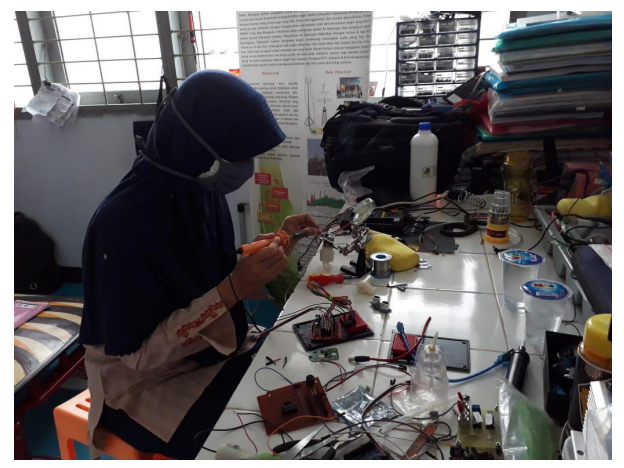

(b)

Gambar 4. Pembuatan Sistem Pencuci Tangan Less Hand Touch, (a) Sistem Mekanik, (b) Sistem Elektronik 
Secara umum, pembuatan sistem pencuci tangan less hand touch dilakukan dalam dua kelompok yaitu bagian mekanik dan bagian elektronik. Pembuatan bagian mekanik dilakukan dengan membuat tiang penyangga sebagai dudukan wastafel seperti pada Gambar 4.a. Sedangkan pembuatan bagian elektronik diawali dengan menghubungkan sensor ultrasonik dengan mikrokontroler (ditunjukkan pada Gambar 4.b). Lebih lanjut, pada sistem elektronik ini juga dilakukan pengontrolan waktu untuk mengeluarkan air, sabun, dan sanitizer sistem. Lebih lanjut, khusus untuk sistem pencuci tangan berbasis sistem pedal, keseluruhan pembuatan dilakukan secara mekanik.

\section{Sistem Pencuci Tangan}

Pada pengabdian ini, sistem pencuci tangan terdiri dari sistem otomatis dan sistem pedal. Pada sistem otomatis, pengeluaran cairan dari sistem dilakukan berdasarkan respon yang diterima oleh sensor dan diteruskan ke mikrokontroler. Ketika sensor membaca atau merespon keberadaan objek (tangan) di depannya, sensor akan mengirimkan sinyal ke mikrokontroler untuk mengeluarkan cairan (air atau sabun) atau tidak. Pada sistem ini, sensor akan merespon keberadaan objek apabila berada pada jarak maksimum $12 \mathrm{~cm}$ di depan sensor. Oleh karena itu, ketika ditempatkan tangan melebihi jarak $12 \mathrm{~cm}$, maka mikrokontroler tidak akan mengeluarkan air atau sabun. Apabila tangan ditempatkan dalam jarak $12 \mathrm{~cm}$, maka respon awal yang diberikan oleh sistem adalah mengeluarkan air selama 2 detik untuk membasahi tangan. Selanjutnya adalah sistem akan mengeluarkan sabun selama 2 detik. Setelah sabun keluar, terdapat jeda waktu 20 detik hingga air keluar untuk membilas tangan. Pengontrolan tahapan pencucian tangan ini dilakukan berdasarkan rekomendasi dari Kementerian Kesehatan Republik Indonesia. Waktu total untuk memberi sabun dan menggosok tangan pada proses mencuci tangan ini adalah 60 detik sebagaimana rekomendasi dari Kementerian Kesehatan Republik Indonesia (Kemenkes RI, 2020; Leo et al., 2021). Tahapan atau langkah mencuci tangan yang dianjurkan oleh Kemenkes ditunjukkan pada Gambar 5.
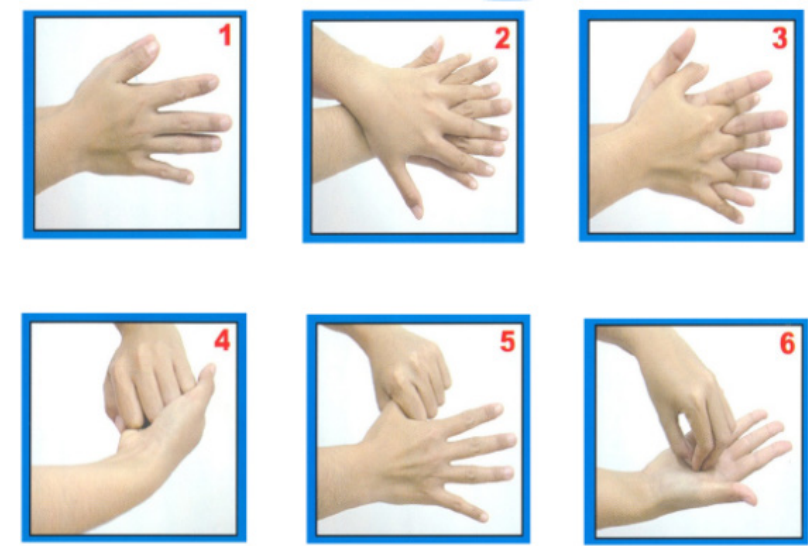

Gambar 5. Enam Langkah Mencuci Tangan

(Putra, 2020; Infodatin, 2014)

Langkah pertama dengan membasahi tangan dan menggosok sabun pada permukaan tangan, langkah berikutnya mengusap dan menggosok kedua punggung tangan, sela-sela jari, ujung jari, ibu jari, dan terakhir meletakkan ujung jari ke telapak tangan kemudian digosok dan dibilas.

Lebih lanjut, pada bagian bawah wastafel pencuci tangan dilengkapi dengan air dan sabun yang digunakan pada proses pencucian tangan. Sedangkan air bekas pencucian dapat dialirkan langsung menggunakan selang menuju saluran pembuangan ataupun ditampung menggunakan wadah khusus. Sistem pencuci tangan otomatis yang dibuat dapat dilihat pada Gambar 6(a).

Untuk pencuci tangan berbasis sistem pedal, pembuatan sistem less hand touch-nya tidak menggunakan perangkat elektronik, namun menggunakan kaki sebagai pengontrol volume cairan yang digunakan ketika mencuci tangan. Sistem pencuci tangan berbasis pedal yang telah dibuat ditampilkan pada Gambar 6(b). Pada sistem ini, terdapat dua pedal yang digunakan untuk mengeluarkan cairan. Pedal sebelah kanan digunakan untuk mengeluarkan sabun, sedangkan pedal sebelah kiri untuk mengeluarkan air. Lebih lanjut, volume cairan yang keluar pada sistem ini bergantung pada kekuatan kaki ketika menekan pedal, semakin kuat kaki maka akan semakin banyak volume cairan yang akan keluar dan berlaku sebaliknya. Pada sistem ini, pipa air dapat dihubungkan langsung dengan saluran air di mana sistem pedal ditempatkan. 


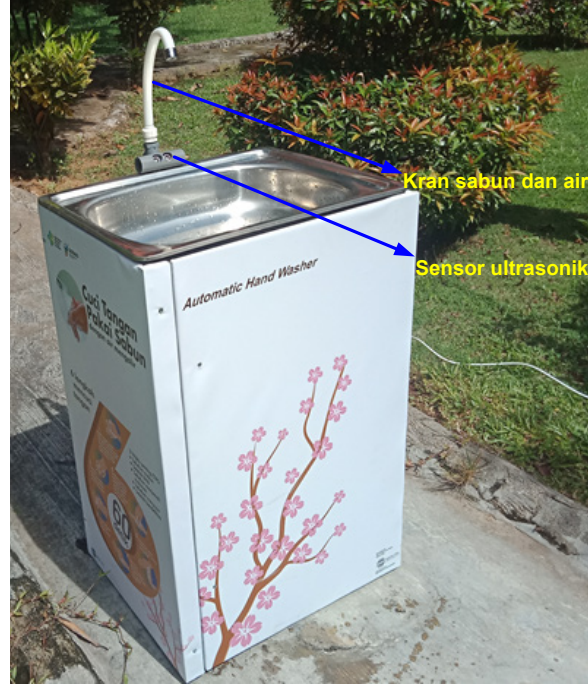

(a)

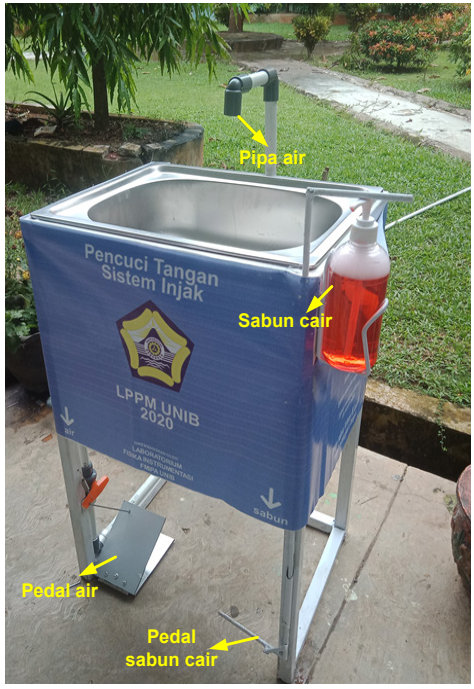

(b)

Gambar 6. Sistem Pencuci Tangan, (a) Sistem Otomatis, (b) Sistem Pedal

\section{Sistem Hand Sanitizer Otomatis-}

Pembuatan sistem hand sanitizer otomatis juga dilakukan dengan dua tahap, yaitu pembuatan bagian mekanik dan bagian elektronik. Pembuatan bagian mekanik yang dimaksud adalah bagian untuk menempatkan cairan sanitizer beserta saluran untuk mengeluarkannya dan bagian elektronik adalah sensor dan mikrokontroler yang akan mengatur volume cairan sanitizer yang dikeluarkan. Pada sistem ini, jarak maksimum antara objek (tangan) dengan sensor adalah $10 \mathrm{~cm}$. Ketika tangan ditempatkan dengan jarak maksimum $10 \mathrm{~cm}$ di depan sensor, maka cairan sanitizer akan keluar otomatis selama 3 detik. Sistem hand sanitizer otomatis yang telah dibuat dapat dilihat pada Gambar 7. Berdasarkan Gambar 7, kotak berwarna hitam di bagian bawah botol sanitizer digunakan untuk menempatkan

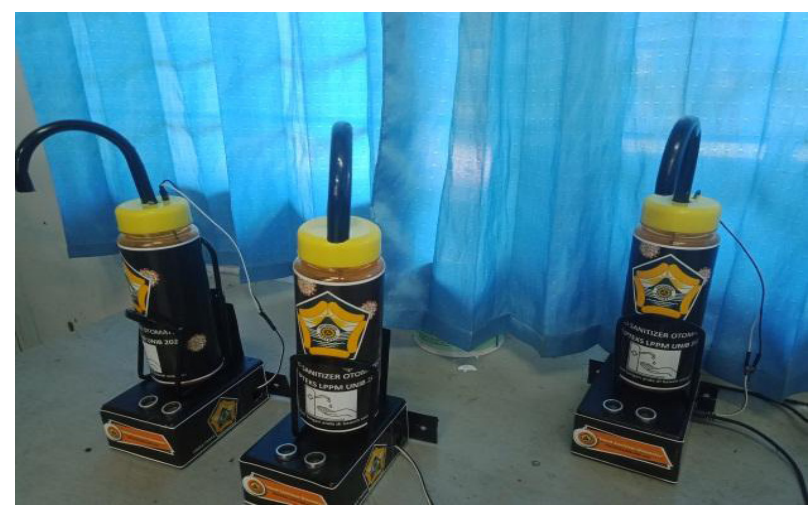

Gambar 7. Sistem Hand Sanitizer Otomatis sistem elektronika termasuk sensor. Sistem ini telah dirancang dengan baik sehingga ketika tangan ditempatkan di atas sensor, maka cairan sanitizer akan langsung keluar dan tertampung pada tangan pengguna.

\section{Serah Terima Sistem Pencuci Tangan}

Selanjutnya ketika semua sistem less hand touch telah selesai dibuat, maka dilakukan serah terima sistem tersebut kepada penyedia layanan umum yaitu tempat ibadah, kantor kelurahan, dan puskesmas. Pencuci tangan otomatis diserahkan pada Puskesmas Beringin Raya Jl. Budi Utomo, Bengkulu dan Masjid Jihadul Ikhsan Attoyibin, Jl. WR. Supratman, Bengkulu. Pencuci tangan sistem pedal diserahkan pada Puskesmas Jembatan Kecil, Kelurahan Jembatan Kecil, Bengkulu, dan Masjid An Naafii SDN 69, Bengkulu. Sistem hand sanitizer otomatis diserahkan pada Kantor Lurah Beringin Raya, Jl. Budi Utomo, Bengkulu, Masjid Fathul Jannah, Jl. WR. Supratman, Bengkulu.

Setelah serah terima alat, maka dilakukan pelatihan penggunaan alat yang telah diberikan kepada pihak penerima sistem less hand touch. Pada penerima peralatan pencuci tangan dijelaskan masing-masing bagian utama yang membangun keseluruhan sistem dan fungsinya. Prinsip kerja peralatan mulai dari menyalakan bagian elektronik hingga dapat bekerja otomatis untuk mencuci tangan pengguna, mengoperasikan sistem mekanik sehingga 
aktivitas mencuci tangan dapat berlangsung dan indikator apa saja pada peralatan. Pada pelatihan ini juga disampaikan beberapa hal seperti bagaimana mengganti apabila cairan (air, sabun, atau sanitizer) habis, apa yang harus dilakukan apabila sistem tidak bekerja dengan semestinya dan bagaimana menempatkan sistem elektronik yang menggunakan sumber listrik agar aman, dan beberapa hal lainnya. Sedangkan pemeliharaan peralatan disampaikan lebih erat tentang penempatan posisi peralatan pada lokasi untuk terlindung dari hujan dan pemantauan ketersediaan air atau sabun dan sanitizer secara rutin. Selanjutnya masing-masing penerima peralatan melakukan uji coba penggunaan alat less hand touch. Penanggungjawab pada setiap lokasi mencoba secara langsung peralatan tersebut mulai dari mengaktifkan peralatan elektronik hingga keseluruhan sistem dapat bekerja dengan melakukan cuci tangan.

Gambar 8 adalah beberapa dokumentasi kegiatan serah terima dari peralatan yang telah dilakukan oleh tim pengabdian. Secara umum, penyerahan peralatan ini dilakukan untuk berbagai fasilitas umum yang berada di sekitar kampus utama Universitas Bengkulu. Gambar 8(a) merupakan dokumentasi serah terima peralatan di Puskemas Beringin Raya yang pada saat itu diterima langsung oleh kepala puskesmas, salah satu karyawan puskesmas, dan penanggung jawab keamanan pada puskesmas tersebut. Sedangkan Gambar 8 (b,c,d) adalah proses pengujian penggunaan peralatan cuci tangan oleh pihak penerima. Pihak penerima khususnya penanggung jawab dalam pemeliharaan alat dapat mengetahui tahapan atau langkah kerja penggunaan alat dengan praktik secara langsung.

Penyerahan bantuan peralatan less hand touch ini diharapkan dapat membantu mengurangi penyebaran Covid-19, menjalankan program pemerintah dalam hal menjaga kebersihan diri dan lingkungan serta bakti civitas kampus terhadap masyarakat sekitar. Lebih lanjut, komunikasi dengan pengelola layanan umum sebagai penerima peralatan less hand touch tetap terus dijalin agar jika ada kendala atau masalah dengan peralatan tersebut yang tidak dapat ditangani oleh penanggung jawab dapat langsung dikomunikasikan dengan tim pengabdian. Pengelola fasilitas umum menyambut positif peralatan pencuci tangan otomatis less hand touch karena pada lokasi tersebut belum ada peralatan yang otomatis dan praktis sebagaimana yang telah diberikan.

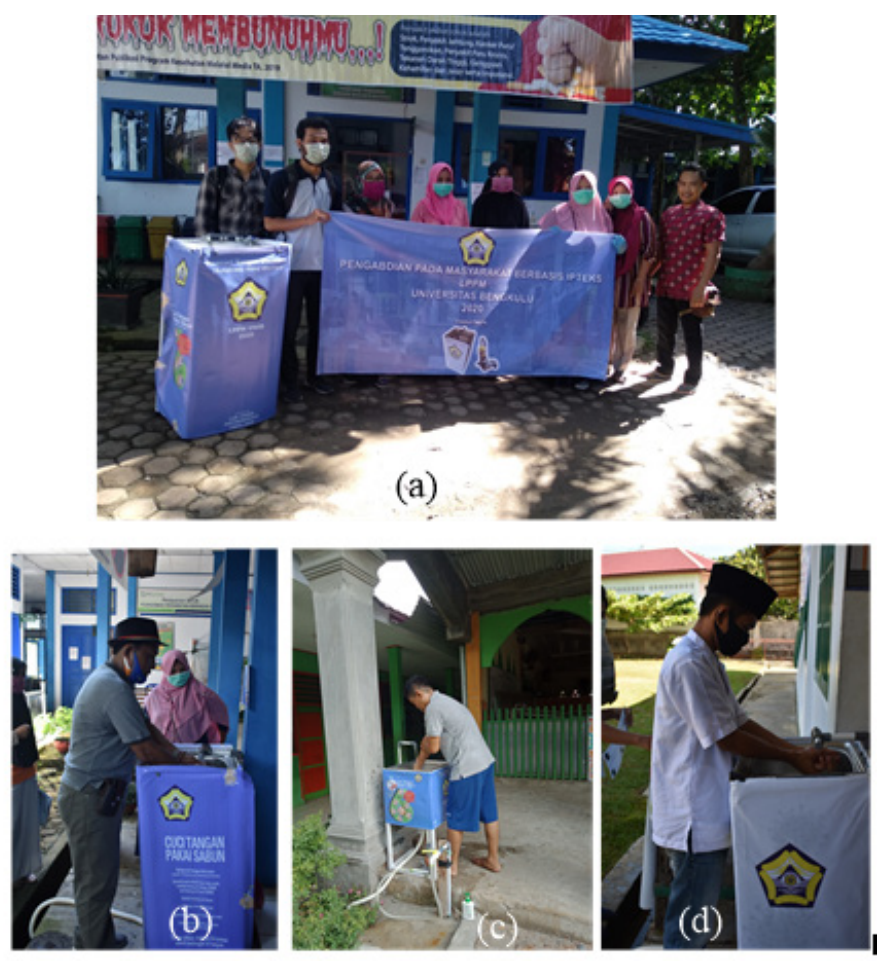

Gambar 8. Serah Terima Peralatan Less Hand Touch 


\section{SIMPULAN}

Berdasarkan hasil kegiatan pengabdian kepada masyarakat yang telah dilakukan dapat disimpulkan bahwa kegiatan secara umum sudah terlaksana dengan baik (100\%), dengan indikasi tercapainya tujuan kegiatan ini berupa pembuatan peralatan less hand touch dan memberikan peralatan tersebut pada beberapa layanan umum yang berada di sekitar kampus Universitas Bengkulu. Penerima bantuan peralatan cuci tangan telah dapat menggunakan alat tersebut secara langsung setelah dilakukan pelatihan mengenai cara penggunaan dan pemeliharaan alat pada saat serah terima peralatan less hand touch. Komunikasi antara tim pengabdian dengan pihak partisipan (pengelola layanan umum) tetap terus dijalin agar jika terdapat permasalahan dapat segera diatasi. Adanya kegiatan pengabdian ini diharapkan dapat membantu mengurangi penyebaran
Covid-19, melaksanakan program pemerintah dan bakti Universitas Bengkulu kepada lingkungan masyarakat sekitar.

Saran dalam kegiatan pengabdian ini antara lain dibutuhkan pelaporan kondisi peralatan secara berkala agar perbaikan dalam hal pengembangan peralatan pada kegiatan lain dapat dilakukan. Semua pengguna alat cuci tangan dibutuhkan juga untuk ikut serta dalam hal menjaga keberadaan alat less hand touch tersebut.

\section{PERSANTUNAN}

Terima kasih ditujukan kepada LPPM Universitas Bengkulu atas pendanaan Pengabdian Berbasis Ipteks khusus Covid-19 yang telah diberikan dengan nomor kontrak: 1502/UN30.15/PM/2020.

\section{REFERENSI}

Chen, L. Der. (2020). Effects of Ambient Temperature and Humidity On Droplet Lifetime- A Perspective of Exhalation Sneeze Droplets with Covid-19 Virus Transmission. International Journal of Hygiene and Environmental Health, 229(May), 113568. https://doi.org/10.1016/j.ijheh.2020.113568

Infodatin. (2014). Perilaku Cuci Tangan Pakai Sabun. Kementerian Kesehatan RI.

Kemenkes RI. (2020). Panduan Cuci Tangan Pakai Sabun. Kesehatan Lingkungan, 20.

Leo, P., Merisca, D. W., Candrayadi, Samsudin, Nugroho, P. B., \& Nainggolan, J. S. (2021). Manajemen Enam Langkah Cuci Tangan menurut Ketentuan WHO sebagai Upaya Pencegahan Covid-19. Jurnal Abdi Masyarakat Humanis, 2(2), 105-113.

Lestari, V., \& Wicaksono, A. P. (2021). Edukasi Protokol Kesehatan di Masa Pandemi Covid-19 pada Warga Dk. Berdug Kulon Rt 01 Rw 11, Sidomulyo, Ampel, Boyolali. Intelektiva : Jurnal Ekonomi, Sosial \& Humaniora Edukasi, 2(09), 96-100.

Meisyaroh, M. S., Sakinah, S., Asnuddin, A., Nurdin, S., Hasrul, \& Murtini. (2021). Penyuluhan Cuci Tangan Pakai Sabun (CTPS) dan Penanganan Covid-19. Jurnal Kreativitas Pengabdian Kepada Masyarakat, 4(1), 234-239.

Mondada, L., Bänninger, J., Bouaouina, S. A., Camus, L., Gauthier, G., Hänggi, P., Koda, M., Svensson, H., \& Tekin, B. S. (2020). Human Sociality in the Times of the Covid-19 Pandemic: A Systematic Examination of Change in Greetings. Journal of Sociolinguistics, 24(4), 441-468. https://doi. org/10.1111/josl.12433

Ogden, R. S. (2020). The Passage of Time During the UK Covid-19 Lockdown. PLoS ONE, 15(7), 1-16. https://doi.org/10.1371/journal.pone.0235871

Przekwas, A., \& Chen, Z. (2020). Washing Hands and the Face May Reduce Covid-19 Infection. Medical Hypotheses, 144(September), 110261. https://doi.org/10.1016/j.mehy.2020.110261

Putra. (2020). Sudah tahu manfaat 6 langkah cuci tangan? Simak di sini. https://doi.org/https:// homecareassistancetracy.com/sudah-tahu-manfaat-6-langkah-cuci-tangan-simak-di-sini/ 
Rosita. (2020). Perang Lawan Corona (Pelakor): Kegiatan Inovasi di Puskesmas Tapunggaya pada Masa Pandemi Covid-19. Prosiding Konferensi Nasional Ilmu Administrasi 4.0, 85-89.

Saputra, A., Iswandi, T., \& Sutarman. (2021). Edukasi Hidup Sehat dan Produktif kepada Masyarakat KPM PKH di Desa Sukamulia Timur pada Era New Normal Covid 19. Bintang: Jurnal Pendidikan Dan Sains, 3(April), 23-33.

Shaputra, R., Gunoto, P., \& Irsyam, M. (2019). Kran Air Otomatis pada Tempat Berwudhu Menggunakan Sensor Ultrasonik berbasis Arduino Uno. Sigma Teknika, 2(2), 192-201.

Subiyanto, P., \& Widyastuti, L. (2021). Best Practices: Collaboration to Prevent the Transmission Covid-19 in Jambangan Spesial Region Yogyakarta. Science Midwifery Journal, 9(1), 307-312.

Suhardi. (2019). Keran Air Otomatis pada Bak Mandi berbasis Arduino Uno Menggunakan Sensor Ultrasonic. ALGORITMA: Jurnal Ilmu Komputer Dan Informatika, 03(1), 48-54.

Tucker, J. S., D’Amico, E. J., Pedersen, E. R., Garvey, R., Rodriguez, A., \& Klein, D. J. (2020). Behavioral Health and Service Usage During the Covid-19 Pandemic Among Emerging Adults Currently or Recently Experiencing Homelessness. Journal of Adolescent Health, 67(4), 603-605. https://doi. org/10.1016/j.jadohealth.2020.07.013

WHO. (2020). Getting your workplace ready for COVID-19. World Health Organization, March, 1-8. www.WHO.int\%0Awww.WHO.int.

Yanti, N. P. E. D., Nugraha, I. M. A. D. P., Wisnawa, G. A., Agustina, N. P. D., \& Diantari, N. P. A. (2020). Public Knowledge About Covid-19 and Public Behavior During the Covid-19 Pandemic. Jurnal Keperawatan Jiwa, 8(4), 491. https://doi.org/10.26714/jkj.8.4.2020.491-504

Zhang, H., Huang, G., Gong, C., Yang, Y., \& Pan, Y. (2020). Corona Discharge-Induced Water Droplet Growth in Air. IEEE Transactions on Plasma Science, 48(7), 2437-2441. https://doi.org/10.1109/ TPS.2020.2999912 